\title{
KAJIAN PENULISAN TUGAS AKHIR MAHASISWA PROGRAM STUDI PENDIDIKAN BAHASA JAWA FAKULTAS BAHASA DAN SENI UNIVERSITAS NEGERI YOGYAKARTA
}

\author{
Suharti, Endang Nurhayati, Venny Indria Ekowati, dan Hartanto Utomo \\ Universitas Negeri Yogyakarta \\ suharti@uny.ac.id, endang_fbs@yahoo.com, venny@uny.ac.id
}

\begin{abstract}
This study is proposed for eight months. The purposes of the study are: (1) identifying the fields of science and sub-fields of research science in the thesis or "Tugas Akhir Skripsi" (TAS) of Javanese Department Students in Faculty of Language and Arts, Yogyakarta State University, (2) identifying the reason for choosing a title, (3) identifying the criteria of thesis supervisor according to the students and alumni of the Javanese Department in Faculty of Language and Arts, Yogyakarta State University, (4) identifying suggestions and criticism from the students and alumni of Javanese Department in Faculty of Language and Arts, Yogyakarta State University related to "TAS". The outcomes of the study are: (1) the data base regarding to the fields of science and sub-fields of research science in "TAS" of Javanese Department students of Faculty of Language and Arts, Yogyakarta State University, (2) reasons for choosing a title, (3) criteria of ideal thesis supervisors according to the students and alumni of Javanese Department in Faculty of Language and Arts, Yogyakarta State University, (4) suggestions and criticism of the students and alumni of Javanese Department in Faculty of Language and Arts, Yogyakarta State University related to "TAS", and (5) a national seminar papers and journals that are not accredited. This study is a survey research using descriptive method with 100 students as the respondents. Based on the findings of the discussion, it can be concluded that: (1) the fields of linguistics as well as the sub-fields of morphology is a field of research the most studied by the students of Javanese Department, (2) reason for choosing a title and topic of thesis by the students is because the students are glad to the field of science and topic taken, (3) the main criteria of the ideal supervisor according to the students of Javanese Department is the appropriateness between the supervisors' field of science and the thesis that is done by the students, (4) respondents noted that they do not agree if the topic and thesis titles are chosen by the Department because of the diversity of the students ability.
\end{abstract}

Keywords: thesis, Javanese Department

\begin{abstract}
Abstrak
Penelitianini bertujuan untuk: (1) Mengindentifikasi bidang ilmu dan sub bidang ilmu penelitian dalam Tugas Akhir Skripsi (TAS) mahasiswa Program Studi Pendidikan Bahasa Jawa FBS UNY, (2) Mengidentifikasi alasan pemilihan judul, (3) Identifikasi kriteria ideal pembimbing skripsi menurut mahasiswa dan alumni Prodi Pendidikan Bahasa Jawa FBS UNY, (4) Mengidentifikasi saran dan kritik mahasiswa serta alumni Prodi Pendidikan Bahasa Jawa FBS UNY terkait TAS. Jenis penelitian ini adalah penelitian survey dengan metode deskriptif dengan jumlah responden 100 orang mahasiswa maupun alumni Prodi Pendidikan Bahasa Jawa FBS UNY. Penelitian ini menggunakan metode survey. Berdasarkan hasil pembahasan dapat disimpulkan bahwa: (1) Bidang ilmu linguistik serta sub bidang morfologi merupakan bidang penelitian yang paling banyak dikaji, (2) Alasan pemilihan judul dan topik skripsi adalah karena mahasiswa senang terhadap bidang ilmu dan topik yang diambil, (3) Kriteria utama seorang pembimbing yang ideal adalah kesesuaian bidang ilmu pembimbing dengan skripsi yang dikerjakan, (4) Responden
\end{abstract}


menyatakan tidak setuju jika topik dan judul skripsi dipilihkan oleh prodi dengan alasan utama keberagaman kemampuan mahasiswa.

Kata kunci: tugas akhir skripsi, Prodi Pendidikan Bahasa Jawa, FBS UNY

\section{PENDAHULUAN}

Karya penelitian yang dilakukan mahasiswa sebagai salah satu syarat kelulusan S-1 bagi mahasiswa Prodi Pendidikan BahasaJawasifatnya wajib dilakukan. Karya ini merupakan Tugas Akhir Skripsi (TAS) yaitu Tugas Akhir Skripsi. Mata kuliah TAS memiliki bobot 6 SKS. Mata kuliah ini dapat diambil oleh mahasiswa jika mahasiswa telah menempuh sekurang-kurangnya 110 SKS, IPK sekurang-kurangnya 2,50, memiliki nilai D maksimal 10\% dari SKS yang ditempuh, mendapat rekomendasi dari penasehat akademik, minimal telah mengikuti seminar atau lokakarya ilmiah yang relevan, dan menandatangani kontrak penulisan (Tim Penulis Panduan TAS, 2015:1-2; Pardjono, dkk. 2014: 9). Seorang mahasiswa dalam menulis skripsi diarahkan dan dibimbing oleh satu atau dua orang pembimbing yang ditugasi oleh fakultas melalui prodi. Waktu penulisan TAS menurut peraturan dilakukan maksimal selama 16 bulan, dan waktu ini disepakati oleh mahasiswa dan dosen dalam bentuk kontrak bimbingan.

Berdasarkan observasi, penulisan TAS di Prodi Pendidikan Bahasa Jawa sejauh ini ditemukan kurang lebih 25\% mahasiswa yang selesai kurang dari jatah waktu yang ditetapkan. Sedangkan 75\% mahasiswa gagal menyelesaikan Tugas Akhir Skripsi tepat waktu, bahkan rata-rata penyelesaiannya lebih dari 16 bulan. Lamanya penyelesaikan tugas akhir skripsi ini menyebabkan rata-rata masa studi Prodi Pendidikan Bahasa Jawa masih tinggi. Kurang lebih sebesar 5,8 tahun. Bahkan beberapa mahasiswa tidak mampu menyelesaikan tugas akhir dan terpaksa mengundurkan diri.

Fenomena lambannya penyelesaian tugas akhir skripsi ini berjalan dari tahun ketahun, dan menjadi kebiasaan yang nyaris tidak bisa dicari akar permasalahannya. Bahkan sampai sekarang ini jumlah mahasiswa Program Studi Pendidikan Bahasa Jawa yang sedang dalam proses penyelesaian tugas akhir skripsi dari angkatan 2008 (yang mengambil dua kali cuti), 2009, 2010, dan 2011 mencapai 98 orang mahasiswa. Progres tugas akhir mereka pun beragam. Mulai dari mahasiswa yang baru saja mendapat judul, mulai menyusun proposal, selesai menyusun proposal, mengerjakan awal bab IV, dan lainlain.

Salah satu faktor yang menyebabkan lambatnya penyelesaikan tugas akhir adalah ketidakseimbangan antara jumlah mahasiswa dan dosen pembimbing. Hal ini akibat dari menumpuknya bidang ilmu dan sub bidang ilmu pada skripsi yang dipilih oleh mahasiswa. Akibatnya, dosen yang sesuai dengan bidang ilmu yang banyak diminati tersebut mempunyai terlalu banyak mahasiswa bimbingan. Selama ini diterangarai bidang ilmu linguistik paling banyak dipilih dalam TAS, namun sampai saat ini belum ada pemetaan jumlah mahasiswa yang mengambil bidang ilmu tersebut. Selain itu, sub-sub bidang ilmu yang dipilih mahasiswa dalam TAS juga belum teridentifikasi dengan jelas.

Terkait dengan penulisan TAS, perlu juga diidentifikasi pendapat mahasiswa maupun alumni mengenai proses pembimbingan dan pembimbing skripsi yang ideal. Penelitian ini diharapkan dapat mengidentifikasi masalah seputar tugas akhir skripsi, terutama dalam ketimpangan bidang ilmu dan sub bindang ilmu dalam TAS. Permasalahan mengenai TAS seperti ini harus diselesaikan karena keterlambatan penyelesaian TAS sangat berdampak dalam berbagai segi. Keterlambatan penulisan TAS berdampak pada jumlah mahasiswa yang terus bertambah. Akibatnya rasio dosen dengan mahasiswa tidak seimbang. Hal ini tentunya akan berdampak tidak baik pada akreditasi prodi. Untuk itu perlu dicari akar permasalahan dan dicarikan solusi yang tepat, agar hal semacam itu dapat 
terselesaikan dengan baik dan tepat sasaran. Berdasarkan alasan-alasan tersebut maka pada kesempatan ini akan dilakukan pengkajian dengan dengan maksud mencari akar permasalah dan solusi apa yang harus dilakukan, agar masalah-masalah seputar TAS tersebut dapat teratasi.

\section{Tugas Akhir Skripsi}

Tugas Akhir adalah karya ilmiah yang disusun oleh mahasiswa setiap program studi berdasarkan hasil penelitian suatu masalah yang dilakukan secara seksama dengan bimbingan dosen pembimbing. Tugas akhir merupakan salah satu persyaratan kelulusan mahasiswa. Ketentuan-ketentuan mengenai tugas akhir diatur oleh masing-masing fakultas, dengan mengikuti standar universitas. Tugas akhir bagi mahasiswa program diploma III berbentuk paper atau proyek akhir. Untuk program sarjana berbentuk skripsi. Jika, mahasiswa tidak dapat menyelesaikan Tugas Akhir Skripsi (TAS), dapat menggantikannya dengan Tugas Akhir Bukan Skripsi (TABS). Mengenai TABS diatur di masing-masing fakultas. Untuk program magister tugas akhirnya berbentuk tesis dan tugas akhir untuk program doktoral berbentuk disertasi. Mengenai tata cara penelitian masingmasing tugas akhir di atur masing-masing fakultas (untuk program studi sarjana) dan program pascasarjana (untuk program studi magister dan doktor) (http://www.uny.ac.id/akademik/tugas-akhir).

Tugas akhir merupakan bentuk pertanggungjawaban ilmiah sekaligus pemberian kesempatan kepada mahasiswa agar dapat memformulasikan ide, konsep, pola berpikir, dan kreativitasnya yang dikemas secara terpadu dan komprehensif, serta dapat mengkomunikasikan dalam format yang lazim digunakan di kalangan masyarakat ilmiah.

\section{Permasalahan Seputar Tugas Akhir Skripsi di Prodi Pendidikan Bahasa Jawa}

Permasalahan seputar TAS di Prodi Pendidikan Bahasa Jawa antara lain: Rasio pembimbingan dosen dan mahasiswa bimbingan yang kurang seimbang. Pada tahun 2015, dosen senior Program Studi yang aktif melakukan bimbingan TAS dan bisa menjadi pembimbing mandiri sejumlah 11 orang. Sedangkan mahasiswa yang sedang menempuh TAS sebanyak 98 orang mahasiswa pada tahun 2015 dan akan bertambah 120 orang mahasiswa di tahun 2016. Sehingga rasio perbandingan antara dosen pembimbingdan mahasiswa bimbingan TAS di tahun 2016 adalah 1:20. Angka ini dirasa cukup tinggi, sehingga dikhawatirkan dosen kurang maksimal dalam melakukan pembimbingan. Apalagi jika bidang ilmu yang dipilih mahasiswa tidak merata.

Masalah lain yang sering ditemui adalah banyaknya mahasiswa yang tidak aktif melakukan bimbingan TAS dengan berbagai permasalahan klasik seperti: bekerja, sudah menikah dan mempunyai anak, masalah kesehatan, masalah biaya, masalah keluarga, dan lain-lain. Masalah lain yaitu stagnasi penulisan karena sumber penelitian yang tidak tepat, data kurang representatif, saran penggantian metode oleh dosen yang tidak segera ditindaklanjuti, dan lain-lain.Selain itu, masalah juga timbul karena kurangnya komunikasi antara dosen dan mahasiswa sehingga mahasiswa tidak mampu mencapai progress yang optimal dalam penyelesaian TAS. Motivasi rendah, malas, mahasiswa takut bertemu dengan dosen pembimbing juga merupakan masalah yang sering muncul. Pembimbing sulit ditemui, minimnya waktu bimbingan juga merupakan masalah klasik dalam proses pembimbingan TAS.

\section{METODE PENELITIAN}

Jenis penelitian ini adalah penelitian survey dengan metode deskriptif.Penelitian ini dilakukan di Prodi Pendidikan Bahasa Jawa FBS UNY. Waktu penelitian adalah selama 
delapan bulan, yaitu dari bulan April-November 2016. Data yang dikumpulkan pada penelitian ini terdiri dari data sekunder dan data primer. Data sekunder yang dikumpulkan yaitu: kondisi umum pembimbingan di Prodi Pendidikan Bahasa Jawa dan data-data umum lain seperti panduan pembimbingan, panduan penulisan TAS, dan lainlain.Sedangkan data primer yang dikumpulkan adalah: Data-data judul TAS, data-data mengenai bidang ilmu dan sub bidang ilmu yang diminati mahasiswa sebagai objek kajian penulisan TAS, data-data mengenai figur ideal pembimbing skripsi, serta data-data tentang saran dan kritik seputar TAS. Jumlah populasi dalam penelitian ini adalah alumni dan mahasiswa Prodi Pendidikan Bahasa Jawa FBS UNY yang sedang menempuh tugas akhir.Pengambilan sampel penelitian menurut Arikunto (2010: 112), jika subjeknya kurang dari 100 orang sebaiknya diambil semuanya. Jika subjeknya lebih dari 100 orang dapat diambil $10-15 \%$ atau 20-25\%. Sampel dalam penelitian ini ditentukan 100 orang alumni mahasiswa Prodi Pendidikan Bahasa Jawa.

Teknik pengolahan dan analisis data yang digunakan dalam penelitian ini dilakukan dengan perlakuan yang berbeda sesuai dengan jenis data yang diperoleh. Data yang diperoleh dari pendekatan ini diolah melalui tiga tahap yaitu: reduksi data, penyajian data dan penarikan kesimpulan.Uji validitas dilakukan validitas isi (content validity) dan validitas konstruksi (construct validity).

\section{HASIL PENELITIAN DAN PEMBAHASAN}

Bidang Ilmu Penelitian Tugas Akhir Skripsi (TAS)

Jurusan bahasa Jawa memiliki lima bidang ilmu skripsi yang dapat dipilih oleh mahasiswa. Bidang ilmu skripsi tersebut yaitu bahasa, sastra, budaya, filologi, dan pendidikan. Masing-masing mahasiswa memiliki minat tersendiri pada satu bidang. Berdasarkan hasil survey dapat diperoleh hasil sebagai berikut.

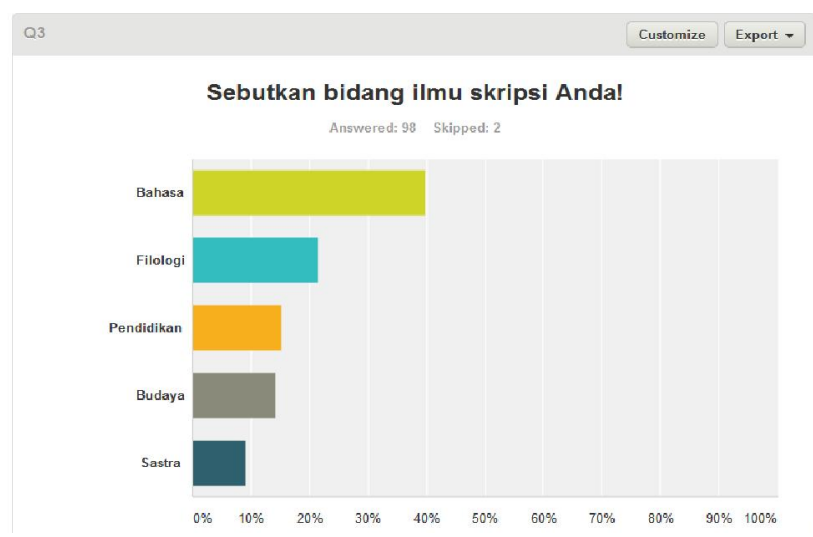

Diagram1. Bidang Ilmu Skripsi

\begin{tabular}{|l|lc}
\hline Answer Choices & Responses & \\
\hline Bahasa & $39.80 \%$ & 39 \\
\hline Filologi & $21.43 \%$ & 21 \\
\hline Pendidikan & $15.31 \%$ & 15 \\
\hline Budaya & $\mathbf{1 4 . 2 9 \%}$ & 14 \\
\hline Sastra & $\mathbf{9 . 1 8} \%$ & 9 \\
\hline Total & & 98 \\
\hline
\end{tabular}

Tabel 1. Prosentase Bidang Ilmu 
Dari data tersebut dapat disimpulkan bahwa 39,80\% mahasiswa bahasa Jawa memilih bidang ilmu bahasa sebagai judul skripsinya. Pada urutan kedua sekitar 21,43\% memilih filologi sebagai judul skripsinya. Bidang ilmu pendidikan diminati sebanyak $15,31 \%$, sedangkan bidang ilmu budaya dipilih oleh $14,29 \%$ responden mahasiswa sebagai bidang ilmu yang dipilih untuk skripsi. Sedangkan bidang ilmu sastra menempati posisi terakhir dengan persentase $9,18 \%$. Bidang ilmu bahasa adalah yang paling diminati sebagai bidang ilmu penelitian skripsi. Prosentase tersebutmenunjukkan bahwa ada ketimpangan yang cukup signifikan yaitu hampir setengah dari seluruh responden memilih skripsi bidang bahasa. Berdasarkan hasil wawancara, disebutkan bahwa skripsi bidang bahasa lebih cepat dikerjakan karena metodenya dianggap lebih pasti dan lebih mudah untuk diterapkan dibandingkan dengan bidang ilmu yang lain.

\section{Sub Bidang Ilmu Bahasa}

Berdasarkan survey yang telah dilakukan, dapat disimpulkan bahwa sub bidang ilmu linguistik yaitu morfologi merupakan sub bidang ilmu yang paling banyak dipilih untuk materi skripsi. Sejumlah $24 \%$ mahasiswa memilih morfologi, diikuti dengan sosiolinguistik dan semantik. Sedangkan yang paling sedikit dipilih yaitu morfosintaksis, sintaksis, morfofonemik, dan LHK (Linguistik Historis Komparatif). Berikut ini diagram yang menunjukkan sub bidang ilmu linguistik yang dipilih oleh mahasiswa Prodi Pendidikan Bahasa Jawa FBS UNY.

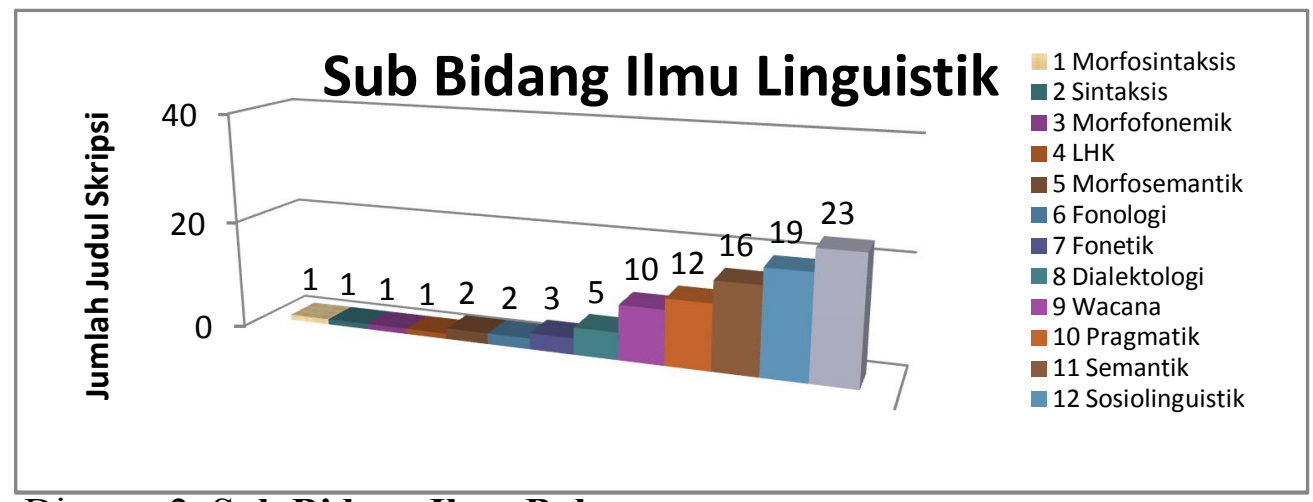

Diagram2. Sub Bidang Ilmu Bahasa

\section{Sub Bidang Sastra dan Budaya}

Persebaran pemilihan sub bidang ilmu sastra ditempati oleh sub bidang ilmu sosiologi sastra di urutan pertama, dan dipilih oleh 17 orang mahasiswa (27\%) dari jumlah keseluruhan. Disusul dengan kajian nilai moral dalam karya sastra yang dipilih oleh 16 mahasiswa (25\%). Majas dan gaya bahasa dipilih oleh 12 orang mahasiswa (19\%), psikologi sastra dipilih 10 orang mahasiswa (16\%). Analisis dan struktur karya sastra dipilih oleh 7 orang mahasiswa (11\%), dan yang paling sedikit yaitu analisis semiotik yang dipilih oleh 1 orang mahasiswa (1\%). Berdasarkan sub bidang ilmu sastra, dapat dilihat bahwa pemilihan judul sub bidang ilmu sastra belum cukup variatif.

Sedangkan pada bidang budaya, sub bidang budaya yang dipilih oleh mahasiswa adalah folklor secara umum, dan upacara tradisi secara khusus. Mahasiswa yang memilih untuk membahas mengenai folklor sebanyak 26 mahasiswa atau (81\%) dan sisanya (19\%) mengambil uparacara tradisi sebagai materi yang dibahas dalam skripsi.

Berikut ini diagram persebaran pemilihan sub bidang ilmu sastra dan budaya. 


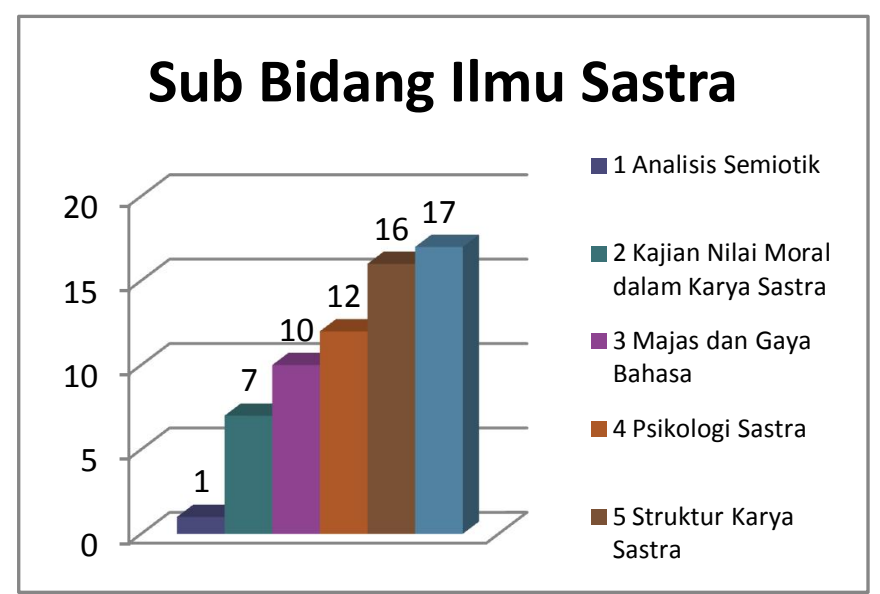

Diagram 3. Sub Bidang Ilmu Sastra

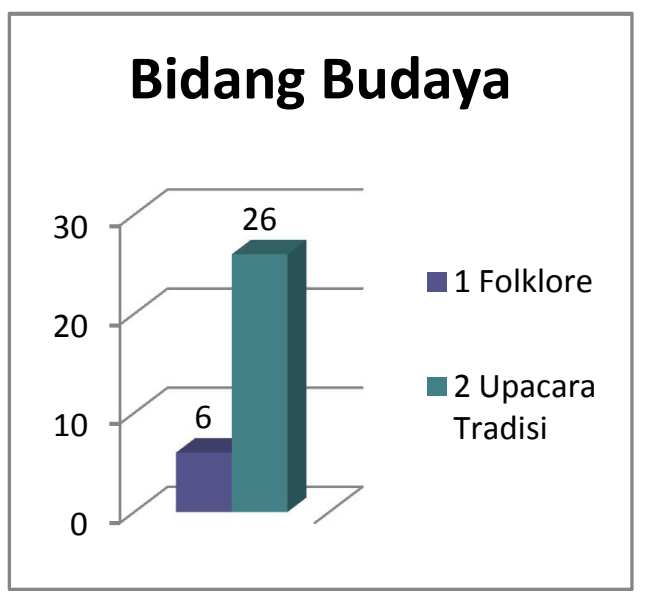

Diagram 4. Sub Bidang Budaya

Untuk sub bidang filologi, terlihat bahwa 100\% mahasiswa memilih sub bidang ilmu filologi modern. Sesuai dengan hasil wawancara dengan responden, pemilihan sub bidang ilmu ini disebabkan filologi modern lebih fungsional karena mengungkap makna variasi suatu teks, dan bukan hanya mencari teks yang paling dekat dengan aslinya. Dengan penelitian modern, teks juga dapat dianalisis secara variatif dan kontekstual berdasarkan kandungan isi naskah.

Untuk sub bidang pendidikan, jenis penelitian yang dipilih oleh mahasiswa hanya dua, yaitu Penelitian Tindakan Kelas (PTK) dan Penelitian Pengembangan (R and D). Untuk jenis penelitian pendidikan, trend jenis penelitian bergeser ke penelitian pengembangan, dikarenakan para mahasiswa menganggap lebih mudah karena lebih sedikit melibatkan pihak lain secara intensif dibandingkan dengan PTK. Berikut ini diagram yang menunjukkan pemilihan jenis penelitian filologi dan pendidikan.

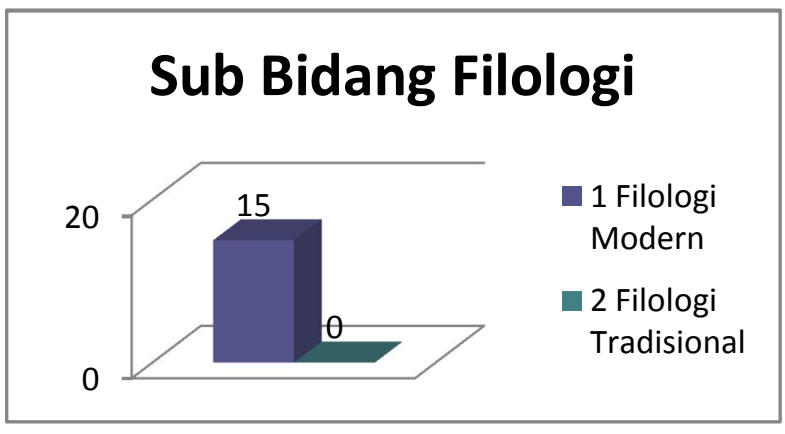

Diagram 5. Sub Bidang Filologi

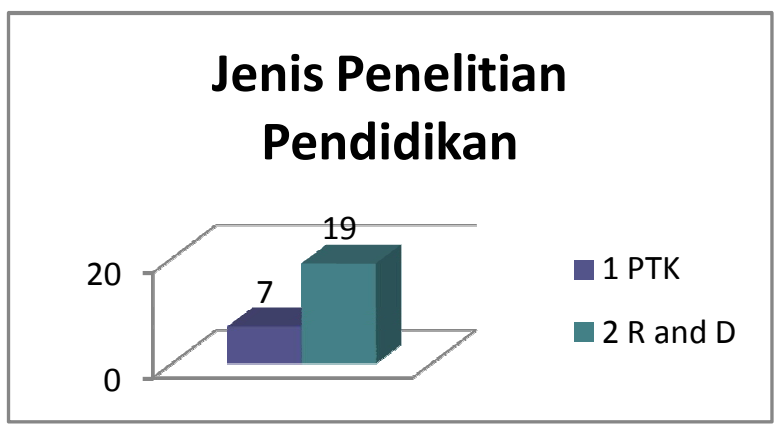

Diagram 6. Jenis Penelitian Pendidikan

\begin{abstract}
Alasan Pemilihan Judul Skripsi
Aspek yang dipertimbangkan mahasiswa dalam memilih judul skripsi cukup beragam. Setelah dilakukan survey baik via online maupun manual dengan menggunakan angket didapatkan hasil bahwa dari 48 responden $(59,26 \%)$ menempatkan alasan memilih judul skripsi karena senang dengan topiknya. Alasan kedua yang paling banyak dipilih adalah "mudah mendapatkan data penelitian". Alasan ini dipilih oleh 24 responden. Alasan "mempunyai kemampuan lebih di bidang yang dipilih", menjadi alasan 12 responden. Sedangkan 4 responden mahasiswa mempunyai alasan sengaja memilih judul tertentu agar mendapat pembimbing tertentu.

Skripsi mudah dikerjakan merupakan alasan 2 responden dalam menentukan judul skripsi. Pada kolom alasan cepat selesai, terdapat2 responden mahasiswa yang memilih
\end{abstract}


kolom tersebut. Kolom yang terakhir menyebutkan bahwa hanya 1 responden yang menjawab bahwa judul skripsi didapatkan dari hasil melanjutkan tugas mata kuliah tertentu. Dari data diatas, dapat disimpulkan bahwa mahasiswa memilih judul skripsi karena senang dengan topik tertentu terlebih jika tersedia banyak data di lapangan. Berikut ini diagram dan tabel yang menunjukkan alasan-alasan pemilihan judul skripsi oleh mahasiswa Prodi Pendidikan Bahasa Jawa FBS UNY

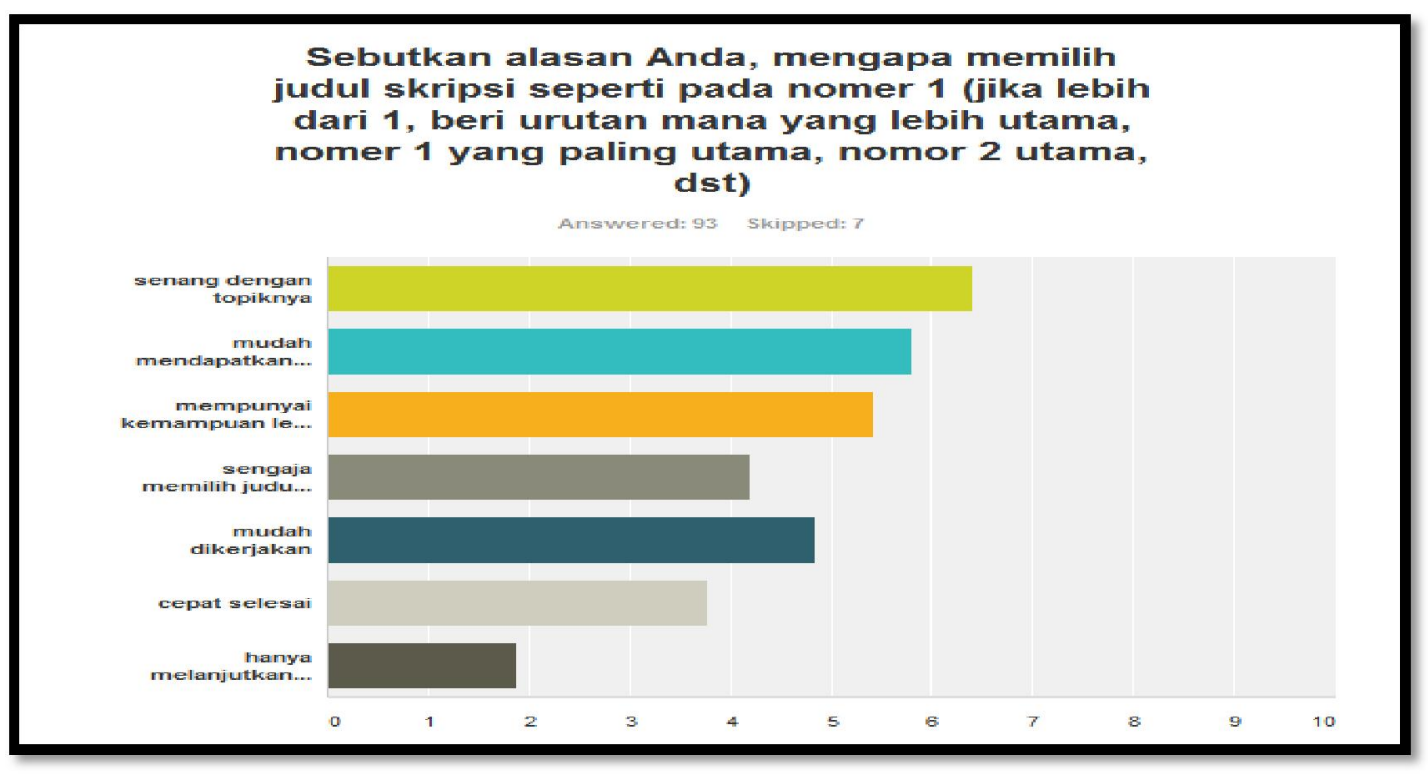

\begin{tabular}{|c|c|c|c|c|c|c|c|c|c|c|}
\hline & $=$ & 1 & 2 & $r$ & 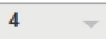 & 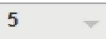 & 6 & 7 & Total - & Score - \\
\hline$F$ & $\begin{array}{l}\text { senang } \\
\text { dengan } \\
\text { topiknya }\end{array}$ & $\begin{array}{r}59.26 \% \\
48\end{array}$ & $\begin{array}{r}32.10 \% \\
26\end{array}$ & $\begin{array}{r}3.70 \% \\
3\end{array}$ & $\begin{array}{r}1.23 \% \\
1\end{array}$ & $\begin{array}{r}2.47 \% \\
2\end{array}$ & $\begin{array}{r}1.23 \% \\
1\end{array}$ & $\begin{array}{r}0.00 \% \\
0\end{array}$ & 81 & 6.41 \\
\hline 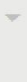 & $\begin{array}{l}\text { mudah } \\
\text { mendapatkan } \\
\text { data }\end{array}$ & $\begin{array}{r}37.50 \% \\
24\end{array}$ & $\begin{array}{r}31.25 \% \\
20\end{array}$ & $\begin{array}{r}17.19 \% \\
11\end{array}$ & $\begin{array}{r}7.81 \% \\
5\end{array}$ & $\begin{array}{r}3.13 \% \\
2\end{array}$ & $\begin{array}{r}0.00 \% \\
0\end{array}$ & $\begin{array}{r}3.13 \% \\
2\end{array}$ & 64 & 5.80 \\
\hline$=$ & $\begin{array}{l}\text { mempunyai } \\
\text { kemampuan } \\
\text { lebih di } \\
\text { bidang yang } \\
\text { dipilih }\end{array}$ & $\begin{array}{r}32.43 \% \\
12\end{array}$ & $\begin{array}{r}32.43 \% \\
12\end{array}$ & $\begin{array}{r}13.51 \% \\
5\end{array}$ & $\begin{array}{r}5.41 \% \\
2\end{array}$ & $\begin{array}{r}2.70 \% \\
1\end{array}$ & $\begin{array}{r}10.81 \% \\
4\end{array}$ & $\begin{array}{r}2.70 \% \\
1\end{array}$ & 37 & 5.43 \\
\hline$v$ & $\begin{array}{l}\text { sengaja } \\
\text { memilih } \\
\text { judul tertentu } \\
\text { agar } \\
\text { mendapat } \\
\text { pembimbing } \\
\text { tertentu }\end{array}$ & $\begin{array}{r}15.38 \% \\
4\end{array}$ & $\begin{array}{r}7.69 \% \\
2\end{array}$ & $\begin{array}{r}30.77 \% \\
8\end{array}$ & $\begin{array}{r}7.69 \% \\
2\end{array}$ & $\begin{array}{r}7.69 \% \\
2\end{array}$ & $\begin{array}{r}26.92 \% \\
7\end{array}$ & $\begin{array}{r}3.85 \% \\
1\end{array}$ & 26 & 4. 19 \\
\hline$\checkmark$ & $\begin{array}{l}\text { mudah } \\
\text { dikerjakan }\end{array}$ & $\begin{array}{r}6.45 \% \\
2\end{array}$ & $\begin{array}{r}32.26 \% \\
10\end{array}$ & $\begin{array}{r}22.58 \% \\
7\end{array}$ & $\begin{array}{r}22.58 \% \\
7\end{array}$ & $\begin{array}{r}9.68 \% \\
3\end{array}$ & $\begin{array}{r}6.45 \% \\
2\end{array}$ & $\begin{array}{r}0.00 \% \\
0\end{array}$ & 31 & 4.84 \\
\hline$\nabla$ & cepat selesai & $\begin{array}{r}11.11 \% \\
2\end{array}$ & $\begin{array}{r}5.56 \% \\
1\end{array}$ & $\begin{array}{r}5.56 \% \\
1\end{array}$ & $\begin{array}{r}22.22 \% \\
4\end{array}$ & $\begin{array}{r}44.44 \% \\
8\end{array}$ & $\begin{array}{r}5.56 \% \\
1\end{array}$ & $\begin{array}{r}5.56 \% \\
1\end{array}$ & 18 & 3.78 \\
\hline- & $\begin{array}{l}\text { hanya } \\
\text { melanjutkan } \\
\text { tugas mata } \\
\text { kuliah } \\
\text { tertentu }\end{array}$ & $\begin{array}{r}0.00 \% \\
0\end{array}$ & $\begin{array}{r}0.00 \% \\
0\end{array}$ & $\begin{array}{r}5.88 \% \\
1\end{array}$ & $\begin{array}{r}11.76 \% \\
2\end{array}$ & $\begin{array}{r}11.76 \% \\
2\end{array}$ & $\begin{array}{r}5.88 \% \\
1\end{array}$ & $\begin{array}{r}64.71 \% \\
11\end{array}$ & 17 & 1.88 \\
\hline
\end{tabular}

\section{Tabel 2. Prosentase Pemilihan Judul Skripsi}

\section{Cara Mendapatkan Gagasan untuk Judul Skripsi}

Terdapat berbagai macam cara yang ditempuh mahasiswa untuk mendapatkan judul skripsi, diantaranya adalah dari ketertarikan pada suatu hal tertentu, melihat judul-judul skripsi kemudian dikembangkan atau divariasikan, mendapatkan masukan dari teman maupun dosen pembimbing, dari hasil membaca buku dan melanjutkan tugas kuliah tertentu. Setelah mengadakan survey, maka diperoleh data sebagai berikut.Sejumlah 48 
responden mahasiswa menyatakan bahwa mereka mendapatkan judul skripsi karena ketertarikan pada suatu hal tertentu. Kemudian setelah diurutkan, cara tersebut disetujui $73,85 \%$ sebagai cara pertama untuk mendapatkan judul skripsi, disusul 16,92\% menempatkan cara tersebut diurutan kedua. Pada urutan ketiga sejumlah 3,08\%, urutan keempat 4,62\%, dan 1,54\% pada urutan kelima.Melihat judul-judul skripsi kemudian dikembangkan dan divariasikan, merupakan salah satu cara yang ditempuh mahasiswa untuk mendapatkan judul skripsi yang nanti akan diteliti. Sebanyak 50\% responden menempatkan cara tersebut sebagai cara yang pertama dan $32,86 \%$ menempatkannya sebagai alasan kedua. Sebanyak $15,71 \%$ responden mahasiswa menempatkannya pada urutan ketiga dan 1,43\% pada urutan keempat.

Saran teman ternyata sangat berpengaruh pada pemilihan judul skripsi mahasiswa tingkat akhir, ini dibuktikan sebanyak 18,18\% mahasiswa menempatkan cara tersebut pada urutan pertama dan kedua.Selain dari teman, mahasiswa juga menerima saran dosen untuk memilih judul skripsi, ini dibuktikan dengan hasil survey dengan hasi19,86\% memilih cara tersebut pada urutan pertama. Persentase yang cukup besar yaitu 45,16\% responden mahasiswa menempatkan cara ini pada urutan kedua dan 16,13\% pada urutan ketiga. Pada urutan keempat dan kelima, memiliki persentase yang sama yaitu $12,90 \%$ sedangkan pada urutan terakhir dipilih oleh 3,23\%.

Membaca buku juga dapat memancing gagasan dalam penentuan judul skripsi. Sebanyak 10\% responden mahasiswa menyetujui jika cara tersebut merupakan cara pertama untuk mendapatkan inspirasi judul skripsi. Pada urutan kedua dan ketiga menunjukkan persentase yang sama yaitu sebanyak 33,33\%, sedangkan yang memilih urutan keempat sebanyak $10 \%$. Sebanyak $13,33 \%$ responden mahasiswa menempatkan pada urutan kelima.Pada pilihan terakhir, yaitu melanjutkan tugas kuliah tertentu dipilih oleh $5,56 \%$ responden sebagai cara pertama dalam proses mendapatkan gagasan untuk judul skripsi. Sebanyak 33,33\% pada urutan kedua. Diagram yang menunjukkan cara untuk mendapatkan gagasan judul skripsi dapat dilihat di bawah ini.

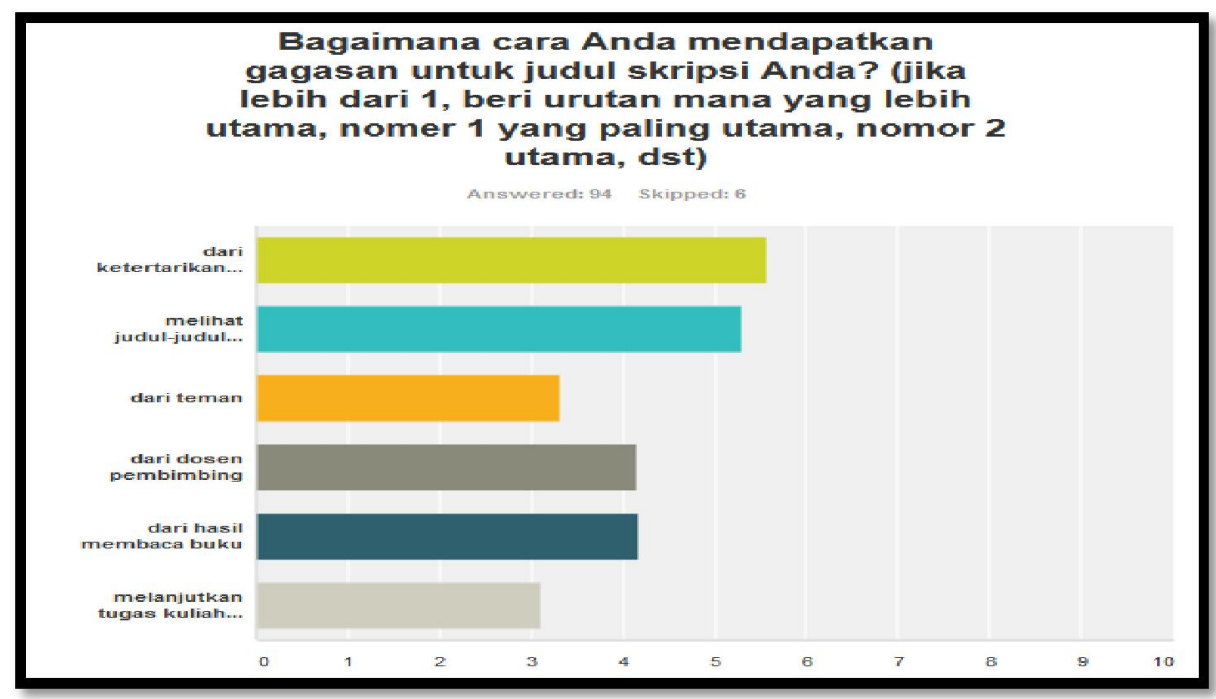

Diagram 8. Cara Mendapatkan Gagasan untuk Judul Skripsi

\section{Kriteria Ideal Pembimbing Skripsi}

Menurut Hariyati (2012:123) dalam survey kinerja dosen pembimbing skripsi, terdapat beberapa poin yang merupakan kriteria ideal pembimbing skripsi, yaitu sikap terbuka dosen pembimbing skripsi dan kesadaran diri dosen pembimbing skripsi. Pada poin sikap terbuka dosen,tujuh kriteria penilaian yang diambil, yaitu dosen memotivasi mahasiswa memilih topik/judul yang inovatif, dosen membantu merumuskan judul skripsi, 
dosen mengarahkan mahasiswa cara mengakses jurnal elektronik maupun informasi ilmiah cetak, dosen mengarahkan mahasiswa menulis skripsi dalam bahasa indonesia yang baik dan benar beserta detail penulisannya dosen mengarahkan mahasiswa menulis proposal atau skripsi sesuai pedoman yang berlaku, saat bimbingan skripsidosen memberikan penjelasan ulang terhadap revisi/koreksi tertulis yang dilakukan, dosen mengarahkan mahasiswa dan memberi masukan pada saat akan ujian komprehensif.

Sedangkan untuk poin kesadaran diri dosen pembimbing terdapat tiga kriteria penilaian yaituwaktu yang disediakan dosen untuk konsultasi proposal atau skripsi, bersedia konsultasi diluar jadwal bimbingan yang telah disepakati, rentang waktu yang disediakan dosen untuk memeriksa proposal/skripsi.

Setelah disesuaikan dengan kebutuhan mahasiswa Prodi Pendidikan Bahasa Jawa, maka kriteria dosen pembimbing skripsi disusun sebagai berikut.
a. Kesesuaian bidang ilmu
b. Mudah ditemui
c. Mampu memberikan masukan secara keilmuan dengan baik.
d. Sabar dalam membimbing
e. Mampu memberi semangat dan motivasi dalam mengerjakan skripsi
f. Mempunyai waktu khusus untuk bimbingan
g. Cepat dalam memberikan koreksi atau revisi

Setelah diadakan survey, hasilnya dapat ditampilkan dalam diagram berikut ini.

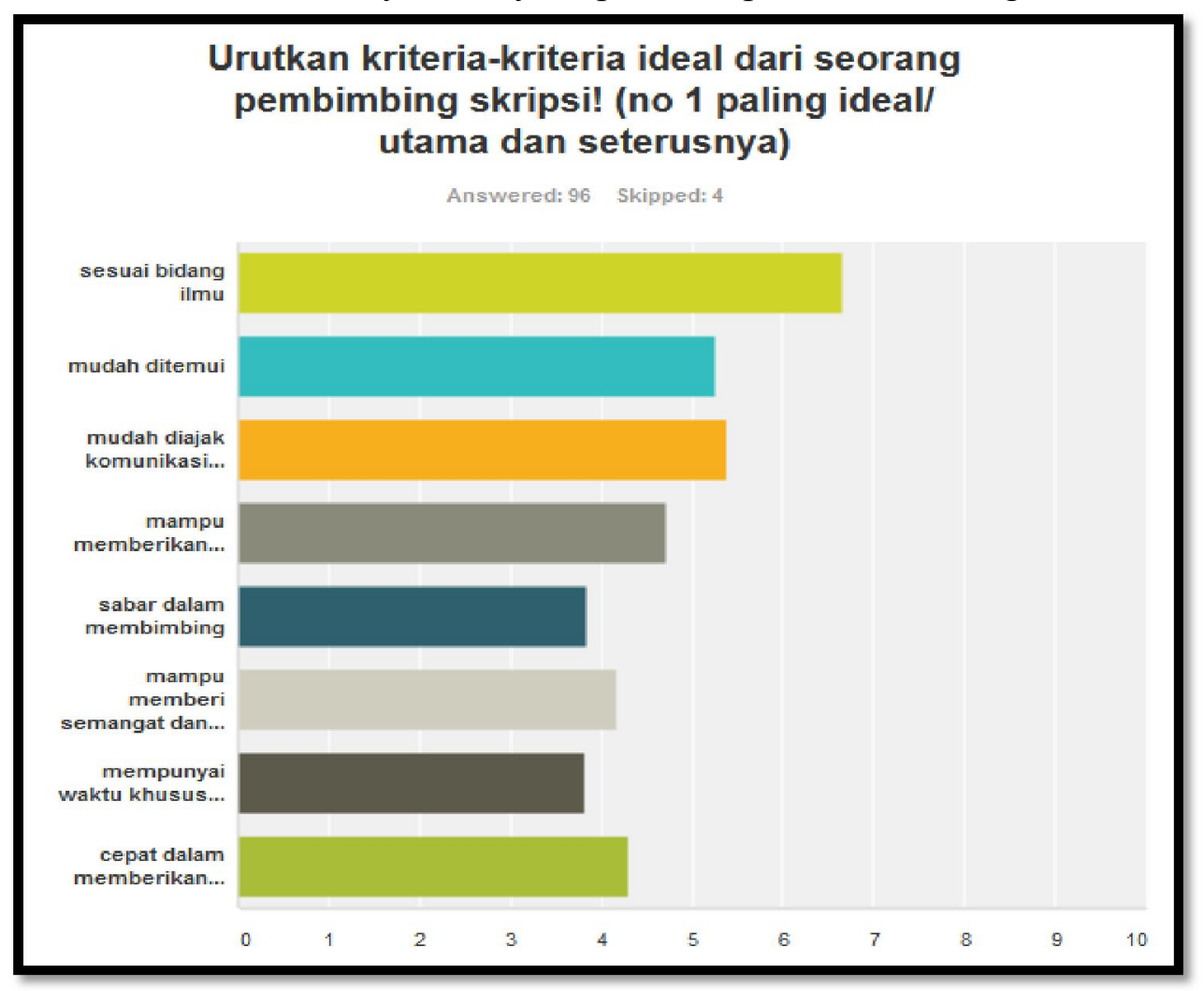

Diagram 8. Kriteria Ideal Pembimbing Skripsi

Berdasarkan diagram 8 di atas, dapat disimpulkan bahwa menurut mahasiswa Prodi Pendidikan Bahasa Jawa hal terpenting dari pembimbing skripsi adalah kesesuaian bidang ilmu skripsi mahasiswa dengan bidang ilmu dosen pembimbing. Hal ini dibuktikan dengan hasil tabulasi data yang menunjukkan bahwa $60 \%$ respoden menganggap bahwa pembimbing yang paling ideal adalah yang sesuai dengan bidang ilmu. Selanjutnya sebanyak 9, 41\% responden menempatkan kriteria tersebut pada urutan kedua dan 5,88\% 
pada urutan ketiga dan keempat. Pada urutan kelima ada 9,41\% serta 3,52\% pada urutan keenam. Adapula urutan ketujuh dan kedelapan dipilih oleh 1,18\% dan 4,71\% responden.

Dosen yang mudah diajak komunikasi (bersedia menerima telpon mahasiswa, membalas email, dan lain-lain) merupakan salah satu kriteria dosen ideal seorang pembimbing skripsi. Setidaknya ini disetujui oleh $11,49 \%$ reesponden yang menempatkan kriteria tersebut pada urutan pertama, 28,74\% pada nomer kedua, 16,09 pada urutan ketiga, $11,49 \%$ pada urutan keempat, 9,20\% pada urutan kelima, $11,49 \%$ pada urutan nomer enam, 9,20\% pada urutan ketujuh, dan 2,30\% pada urutan terakhir.

Dosen yang mudah ditemui juga merupakan tolak ukur ideal seorang pembimbing skripsi. hal ini ditunjukkan dari $17,50 \%$ responden mahasiswa memilih kriteria tersebut sebagai nomer satu, kemudian sebanyak 20\% mahasiswa setuju jika kriteria diatas menduduki urutan kedua, sebanyak $13,75 \%$ dan $11,25 \%$ pada urutan ketiga dan keempat, $11,25 \%$ pada urutan kelima, $13,75 \%$ diurutan ketujuh serta $1,25 \%$ pada urutan terakhir.

Mampu memberikan masukan keilmuan secara baik dan jelas merupakan kriteria seorang dosen pembimbing skripsi. Sebanyak 5,95\% responden memilih kriteria tersebut sebagai kriteria pertama seorang pembimbing skripsi. Sebanyak $19.05 \%$ responden menempatkannya pada urutan kedua dan 14,29\% pada urutan ketiga. Adapula yang menempatkan pada urutan keempat dan kelima sebanyak 16,67\% dan 10,71\% responden. Selanjutnya urutan keenam dipilih oleh sebanyak 17,86\% responden, 9,52\% memilih sebagai urutan ketujuh dan 5,95\% memilih kriteria tersebut sebagai kriteria terakhir.

Kolom kriteria sabar dalam membimbing, dipilih 6,67\% responden sebagai kriteria utama dosen pembimbing yang ideal, 9,33\% responden mahasiswa mengurutkan pada urutan kedua dan ketiga, $12,00 \%$ responden menempatkan di urutan keempat. Sebanyak $17,33 \%$ responden mahasiswa memilih urutan kelima dan $8,00 \%$ memilih urutan keenam. Urutan ketujuh dipilih oleh $20 \%$ responden mahasiswa dan $17,33 \%$ responden mahasiswa memilih kriteria tersebut sebagai kriteria terakhir seorang dosen pembimbing skripsi yang ideal.

Setiap mahasiswa juga membutuhkan motivasi yang berarti dari seorang dosen pembimbing agar lebih semangat mengerjakan skripsi. Sejumlah 5,26\% memilih kriteria tersebut sebagai kriteria pertama, 6,58\% pada urutan kedua, 19,74\% pada urutan ketiga, $13,16 \%$ pada urutan keempat, $15,79 \%$ pada urutan kelima, $14,47 \%$ pada urutan keenam, $13,16 \%$ pada urutan ketujuh, dan $11,84 \%$ pada urutan terakhir.

Seorang dosen yang mempunyai waktu khusus untuk bimbingan, misalnya seminggu sekali dihari tertentu merupakan salah satu kriteria ideal pembimbing skripsi. Berdasarkan hasil survey 4,05\% responden mahasiswa memilih kriteria tersebut sebagai kriteria pertama dan 13,51\% sebagai kriteria kedua. Selanjutnya 10,81\% responden mahasiswa memilihnya pada urutan ketiga dan $13,51 \%$ pada urutan keempat. Sebanyak $9,46 \%$ responden mengurutkan kriteria tersebut pada urutan kelima, 12,16\% pada urutan keenam dan ketujuh, serta $24,32 \%$ pada urutan terakhir.

Kriteria yang terakhir adalah cepat dalam memberikan koreksi atau revisian, kriteria ini disetujui oleh 2,33\% responden mahasiswa memilih kriteria tersebut sebagai kriteria pertama, 9,36\% pada kriteria kedua, 19,77\% pada kriteria ketiga dan keempat, $15,12 \%$ pada kriteria urutan kelima, $12,79 \%$ kriteria keenam, $10,47 \%$ sebagai urutan ketujuh dan terakhir.

\section{Pendapat Mahasiswa tentang Pengaturan Judul Skripsi oleh Prodi}

Seperti yang sudah disebutkan diatas, bahwa terjadi ketimpangan dalam pemilihan bidang ilmu skripsi, maka dari itu sebagai upaya pemerataan bidang ilmu skripsi maka diberikan usulan jika judul skripsi diatur oleh pihak jurusan. Usulan ini tentu saja menjadi 
pro dan kontra diantara para mahasiswa. Maka dari itu diadakan survey untuk mengetahui pendapat mahasiswa tentang wacana tersebut dengan hasil seperti yang tergambar dalam diagram di bawah ini.

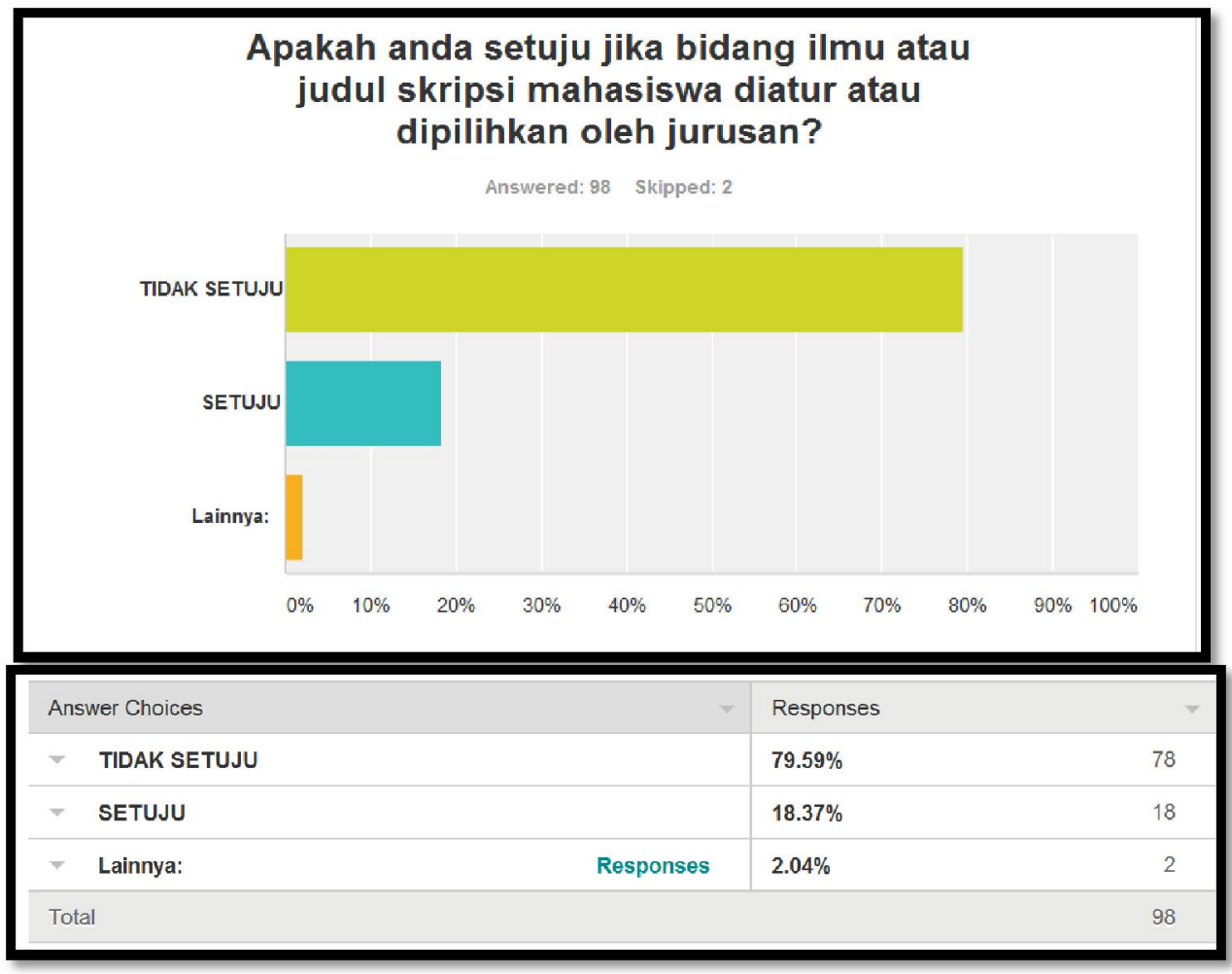

\section{Diagram 9. Pendapat Mahasiswa tentang Pengaturan Judul Skripsi oleh Prodi}

Berdasarkan survey diatas dapat diketahui bahwa 79,59\% mahasiswa tidak menyetujui adanya pengaturan judul skripsi oleh jurusan, sedangkan 18,37\% setuju atas usulan tersebut dan lainnya 2,04\%. Dari survey diatas dapat disimpulkan bahwa sebagian besar responden mahasiswa menolak usulan pengaturan judul skripsi oleh Prodi. Berdasarkan angket terbuka yang diisi oleh responden yang tidak menyetujui jika pemilihan judul skripsi diatur oleh Prodi, dapat disimpulkan adanya tujuh alasan dasaryaitu:

1. Membatasi kreativitas.

2. Mahasiswa memiliki kemampuan yang berbeda.

3. Mahasiswa akan merasa terbebani.

4. Mahasiswa akan kesulitan dalam mengerjakan skripsi.

5. Judul merupakan hak mahasiswa.

6. Skripsi merupakan tanggungjawab pribadi mahasiswa.

7. Skripsi harus sesuai minat mahasiswa. 


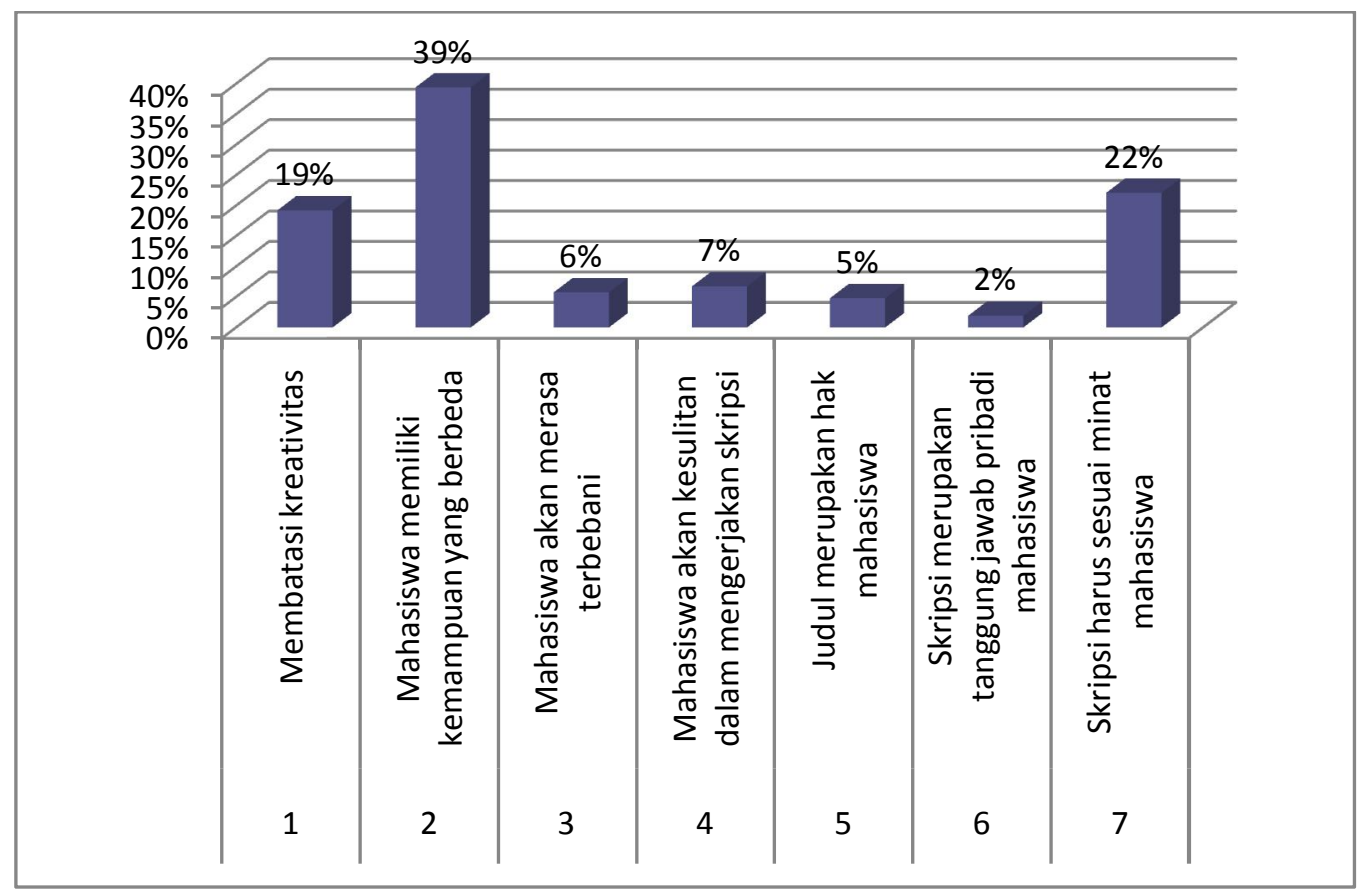

\section{Diagram 9. Alasan Mahasiswa Tidak Setuju Pemilihan Judul Skripsi Diatur Prodi}

Berdasarkan diagram diatas, dapat diketahui bahwa sebanyak 19\%responden memiliki alasan jika wacana pengaturan judul skripsi oleh mahasiswa dapat membatasi kreativitas mahasiswa. Alasan mahasiswa memiliki kemampuan yang berbeda disetujui oleh 39\% responden. Sebanyak 7\% responden merasa jika judul dipilihkan oleh prodi, maka mahasiswa akan merasa terbebani dalam mengerjakan skripsi. Hal ini dapat berdampak mahasiswa menjadi kesulitan untuk menyelesaikannya skripsi. Adapula 5\% responden yang berpendapat jika judul skripsi merupakan hak pribadi mahasiswa. Skripsi merupakan tanggung jawab pribadi mahasiswa, alasan ini disetuji $2 \%$ responden mahasiswa. Alasan terakhir adalah skripsi harus sesuai dengan minat mahasiswa, alasan tersebut disetuji oleh $22 \%$ responden.

Walaupun banyak yang tidak setuju dengan wacana tersebut, namun ada beberapa responden yang menganggap wacana tersebut baik untuk kemajuan jurusan dan mahasiswa Jurusan Bahasa Jawa. Setidaknya ada 18\% responden yang setuju jika judul skripsi diatur oleh pihak jurusan. Dari tabel alasan responden mahasiswa yang menyetujui jika judul skripsi diatur oleh jurusan, dapat ditarik tujuh alasan dasar mahasiswa menyetujui alasan tersebut.

1. Responden menyetujui wacana tersebut, tetapi dengan catatan dikoordinasikan dengan baik.

2. Mahasiswa akan lebih terarah dalam menentukian judul skripsi.

3. Agar mahasiswa tidak kekurangan gagasan dan ide dalam menentukan judul skripsi.

4. Supaya adil.

5. Agar tidak terjadi penolakan judul skripsi.

6. Agar lebih memudahkan mahasiswa.

7. Agar lebih merata dalam memilih bidang ilmu skripsi.

Dari alasan tersebut dapat disajikan diagram sebagai berikut. 


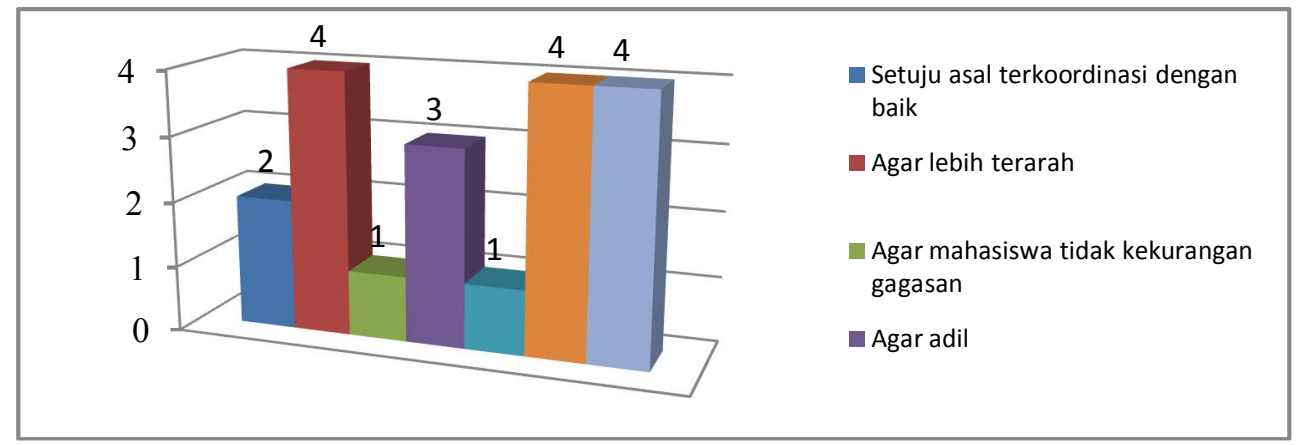

Diagram 10. Alasan Mahasiswa Setuju Pemilihan Judul Skripsi Diatur Prodi

Melihat diagram diatasdapat diketahui bahwa sebanyak 2 responden menyetujui wacana tersebut, tetapi dengan catatan dikoordinasikan dengan baik. Alasan mahasiswa akan lebih terarah dalam menentukan judul skripsi disetujui oleh 4 orang mahasiswa. Ada 1 mahasiswa yang merasa jika hal tersebut tidak dilakukan maka mahasiswa akan kekurangan gagasan dan ide untuk mengerjakan skripsi. Variasi judul skripsi yang adil dan tidak timpang merupakan salah satu alasan yang dikemukakan oleh 3 responden. Adapula 1 responden yang berpendapat agar tidak terjadi penolakan judul skripsi oleh jurusan, alasan keenam yaitu agar mahasiswa lebih mudah dalam menentukan judul skripsi, disetujui oleh 4 responden. Alasan terakhir adalah agar lebih merata dalam memilih bidang ilmu skripsi dipilih oleh 4 responden.

\section{Kritik dan Saran Terkait dengan Tugas Akhir Skripsi}

Dari 100 responden, dapat dirangkum kritik dan saran terkait dengan tugas skripsi sebagai berikut.

1. Harus ada tambahan literatur yang digunakan dalam penulisan skripsi, pembimbing dan mahasiswa memperhatikan kajian teori yang digunakan tidak hanya cuplik sana cuplik sini saja.

2. Adanya penyamaan persepsi dosen tentang istilah-istilah yang digunakan dalam skripsi berbahasa Jawa. Hal tersebut dikarenakan antara dosen satu dan yang lain masih ada yang berbeda pendapat sehingga hal tersebut membuat bingung mahasiswa.

3. Dosen yang sudah ditugaskan sebagai pembimbing sebaiknya lebih mudah ditemui, mudah berkomunikasi dengan mahasiswa bimbingannya, selalu memberi semangat dan motivasi kepada mahasiswa bimbingannya, lebih sabar dalam memberikan bimbingan dan memberikan saran mengenai buku-buku atau sunmber-sumber lain yang dapat digunakan untuk referensi dalam tugas akhir.

4. Responden juga menyarankan agar bimbingan dijadwalkan secara teratur dan sistematis.

5. Prodi mengadakan seminar atau workshop terkait tugas akhir untuk memancing ide-ide dari mahasiswa, dan perlu diadakan percepatan skripsi untuk mahasiswa semester akhir. Memberikan solusi-solusi supaya mahasiswa cepat selesai dalam mengerjakan tugas akhir.

6. Perlu dibudayakan pembimbingan via email atau online agar mahasiswa tidak terlalu banyak yang antri dan terlalu lama menunggu di depan prodi.

\section{SIMPULAN} berikut:

Berdasarkan hasil penelitian dan pembahasan, didapatkan simpulan sebagai 
1. Bidang ilmu linguistik serta sub bidang morfologi merupakan bidang penelitian yang paling banyak dikaji oleh mahasiswa Prodi Pendidikan Bahasa Jawa.

2. Alasan pemilihan judul dan topik skripsi oleh mahasiswa adalah karena mahasiswa senang terhadap bidang ilmu dan topik yang diambil.

3. Kriteria utama seorang pembimbing yang ideal menurut mahasiswa Prodi Pendidikan Bahasa Jawa adalah kesesuaian bidang ilmu pembimbing dengan skripsi yang dikerjakan oleh mahasiswa.

4. Responden menyatakan tidak setuju jika topik dan judul skripsi dipilihkan oleh prodi dengan alasan utama keberagaman kemampuan mahasiswa.

5. Kritik dan saran terkait TAS Prodi Pendidikan Bahasa Jawa adalah sebagai berikut:

a. Harus ada tambahan literatur yang digunakan dalam penulisan skripsi, pembimbing dan mahasiswa memperhatikan kajian teori yang digunakan tidak hanya cuplik sana cuplik sini saja.

b. Semua dosen menyamakan persepsi tentang istilah-istilah dalam bahasa jawa. Hal tersebut dikarenakan antara dosen satu dan yang lain masih ada yang berbeda pendapat sehingga hal tersebut membuat bingung mahasiswa.

c. Sebaiknya dosen pembimbing yang sudah terpilih, lebih mudah ditemui, mudah berkomunikasi dengan mahasiswa bimbingannya, selalu memberi semangat dan motivasi kepada mahasiswa bimbingannya, lebih sabar dalam memberikan bimbingan dan memberikan saran mengenai buku-buku atau sunmber-sumber lain yang dapat digunakan untuk referensi dalam tugas akhir.

d. Bimbingan terjadwal.

e. Dosen mengadakan seminar atau workshop terkait tugas akhir untuk memancing ideide dari mahasiswa, dan perlu diadakan percepatan skripsi untuk mahasiswa semester akhir. Memberikan solusi-solusi supaya mahasiswa cepat selesai dalam mengerjakan tugas akhir.

f. Diadakan bimbingan via email atau online agar mahasiswa tidak banyak antrian di depan jurusan.

g. Prodi Pendidikan Bahasa Jawa merupakan prodi kependidikan, sehingga ke depan sebaiknya semua skripsi dapat dikaitkan dengan bidang kependidikan.

\section{DAFTAR PUSTAKA}

Arikunto, Suharsimi, 2010. Prosedur Penelitian Suatu PendekatanPraktek, Jakarta: Penerbit Rineka Cipta.

Hariyati, Rini Maryuni. 2011. Survey Kinerja Dosen Pembimbing Skripsi dan Kualitas Skripsi Mahasiswa Akuntansi STIE Malangkucecwara. Malang: JDA

Parjono, dkk. 2014. Peraturan AkademikUniversitas Negeri Yogyakarta. Yogyakarta: Kemendikbud UNY.

Rahyono, FX. 2010. Kiat Menyusun Skripsi dan Strategi Belajar di Perguruan Tinggi.Jakarta: penaku.

Sugiyono, (2008). Metode Penelitian Kunatitatif Kualitatif dan R\&D. Bandung Alfabeta.

Sukardi. 2011. Metodologi Penelitian Pendidikan. Yogyakarta: Bumi Aksara.

Tim. 2015. Draf Panduan Penulisan Tugas Akhir, Pembimbingan, dan Mekanisme Ujian TAS/TAS. Belum diterbitkan.

Tim. 2015. Panduan Tugas Akhir. Yogyakarta: FBS UNY. 